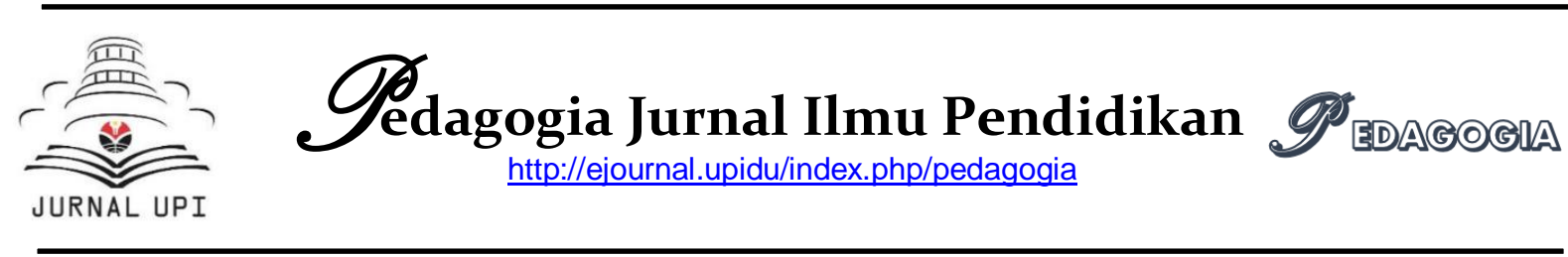

\title{
Pengaruh Pembelajaran Inquiry Based Learning Terhadap Kemampuan Berpikir Kritis Matematik Mahasiswa
}

\author{
Supriadi \\ Universitas Pendidikan Indonesia Kampus Daerah Serang \\ supriadi.upiserang@upi.edu
}

\begin{abstract}
The study aims to improve the quality of the process and results of PGSD student mathematics learning through mathematics learning using inquiry-based learning. Instrument applied in the form of pretes, postes, enquette, interview, journal and observation. Research of experiment with design group of this pretes-postes control applies population of all student Pre-Service Elementary Teachers and the sample semester student 4 at UPI Serang. Result of calculation expressing that student test average learning with inkuiri based learning: approach of structured inquiry, approach of guided inquiry and approach of open inquiry in assures is higher than learning students conventionally. Improvement of ability thinks student mathematics getting study with approach to base on higher inkuiri in significan at $=0,05$ than student getting conventional study. Average group of Science is higher than , group of Social, and group of Language. Improvement of ability thinks mathematics university student group of higher Science in signifikan at $=0,05$ than group of Social and group of Language. Almost entirely student gives position which are positive to study of inquiry based learning.
\end{abstract}

Keywords: Mathematics, Inquiry Based Learning, Critical Thinking

\begin{abstract}
Abstrak
Tujuan penelitian ini adalah untuk meningkatkan kualitas proses dan hasil pembelajaran matematika mahasiswa PGSD melalui pembelajaran matematika menggunakan pembelajaran berbasis inkuiri. Instrumen diterapkan dalam bentuk pretes, postes, enquette, wawancara, jurnal dan observasi. Penelitian eksperimen dengan kelompok desain kontrol pretes-postes ini menggunakan populasi semua siswa Guru Pra-Layanan SD dan siswa semester 4 di UPI Serang. Hasil perhitungan menyatakan bahwa rata-rata tes belajar siswa dengan pembelajaran berbasis inkuiri: pendekatan inkuiri terstruktur, pendekatan inkuiri terbimbing dan pendekatan inkuiri terbuka lebih meyakinkan daripada pembelajaran siswa secara konvensional. Peningkatan kemampuan berpikir matematika siswa mendapatkan pembelajaran dengan pendekatan berbasis inkuiri lebih tinggi secara signifikan pada $=0,05$ daripada siswa yang mendapatkan pembelajaran konvensional. Kelompok Ilmu ratarata lebih tinggi daripada, kelompok sosial, dan kelompok bahasa. Peningkatan kemampuan berpikir kelompok mahasiswa matematika IPA lebih tinggi secara signifikan pada $=0,05$ daripada kelompok sosial dan kelompok bahasa. Hampir seluruhnya siswa memberikan posisi yang positif untuk mempelajari pembelajaran berbasis inkuiri.
\end{abstract}

\begin{tabular}{l}
\hline Article Info \\
\hline Naskah Diterima: \\
2018-12-06 \\
Naskah Direvisi: \\
2019-03-24 \\
Naskah Disetujui: \\
2019-04-24 \\
\hline
\end{tabular}

Kata kunci: Matematika, Pembelajaran Berbasis Inkuiri, Berpikir Kritis 


\section{A. PENDAHULUAN}

\section{Matematika merupakan aspek penting untuk membentuk sikap (Ruseffendi, 2006), sehingga tugas pengajar selain menyampaikan materi matematika dengan baik juga harus dapat membantu pembentukan sikap peserta didiknya.}

Hal tersebut menjadi tugas pengajar untuk memperbaiki anggapan tersebut agar menjadi baik. Padahal pempelajari matematika adalah penting karena dalam kehidupan sehari-hari, kita tidak boleh mengelak dari aplikasi matematika bukan itu saja matematika juga mampu mengembangkan kesadaran tentang nilai-nilai yang secara esensial (Siagian, 2015).

Anggapan negatif terhadap matematika terjadi dalam perkuliahan matematika Pendidikan Guru Sekolah Dasar (PGSD). Matematika masih dianggap sebagai mata kuliah yang sulit dan banyak mahasiswa yang merasa takut jika mengikuti mata kuliah matematika. Anggapan tersebut berdampak pada hasil UTS dan UAS mahasiswa PGSD yang selalu kurang memuaskan.

Dalam penelitiannya Hendriana (2012) menjelaskan bahwa program studi di luar program studi matematika ketika dihadapkan dengan mata kuliah pengenalan statistik (sebagai mata kuliah wajib) merasa tersiksa dengan hitunganhitungan yang diberikan. beberapa mahasiswa di perguruan tinggi yang mengambil Keberagaman mahasiswa yang melatarbelakangi pendidikan mahasiswa PGSD, yakni mereka berasal dari berbagai jurusan, baik IPA, IPS maupun bahasa menjadi salah satu faktor penghambat mahasiswa dalam mengikuti perkuliahan matematika, sehingga masih memungkinkan adanya anggapan negatif terhadap matematika.

Selain permasalahan di atas, faktor yang lainnya adalah lemahnya proses berpikir mahasiswa. Mereka hanya menghafal informasi, mengingat informasi dan mengumpulkannya tanpa memahami informasi yang diperolehnya.

Dari hasil pengamatan yang dilakukan Supriadi (2005) selama beberapa semester terhadap mahasiswa D2 PGSD, S1 PGSD yang berasal dari SMA, SMK, MA dan SPG, dengan program studi IPA dan Non-IPA, ternyata kurang memuaskan dengan diperolehnya rerata kurang dari $50 \%$ dari skor maksimal untuk kedua kelompok tersebut. Mahasiswa masih kesulitan memahami matematika yang dipandangnya mata kuliah yang paling sulit dan tidak menyenangkan. Ekspresi, komunikasi dan kemampuan berpikir matematika di antara mahasiswa masih kurang. Kemudian didukung oleh pengamatan Tiurlina (2005) bahwa pemahaman konsep mahasiswa PGSD masih lemah dan dibawah $50 \%$. Selain itu, mahasiswa PGSD cenderung menyenangi soal-soal yang berbentuk rutin sehingga saat diberikan soal-soal yang bersifat tidak rutin mereka cenderung kesulitan. Pada umumnya kemampuan mahasiswa PGSD dalam penyelesaian permasalahan matematika dapat dikatakan sedang dan rendah, jarang sekali mahasiswa yang berkemampuan tinggi, serta suasana kegiatan belajar mahasiswa PGSD cenderung tidak terlalu aktif.

Fakta lain yang mendukung studi pendahuluan tersebut adalah laporan hasil penelitian. Pertama, Mayadiana (2005) dalam penelitiannya yang berjudul Pembelajaran dengan Pendekatan Diskursif untuk Mengembangkan Kemampuan Berpikir Kritis Mahasiswa PGSD, bahwa kemampuan berpikir kritis mahasiswa calon guru SD masih rendah, yakni mencapai 36,62\% untuk mahasiswa berlatar belakang IPA, 26,62\% untuk mahasiswa berlatar belakang Non-IPA, serta $34,06 \%$ untuk keseluruhan mahasiswa. Kedua, Maulana (2007) dalam 
penelitiannya yang berjudul pendekatan metakognitif sebagai alternatif pembelajaran matematika untuk Meningkatkan Kemampuan Berpikir Kritis Mahasiswa PGSD, bahwa rerata kemampuan berpikir kritis mahasiswa calon guru SD sebesar 33,3\%. Ketiga, pengamatan Supriadi (2005), bahwa nilai tes berpikir kritis mahasiswa calon guru SD masih kurang memuaskan, yakni dengan terlihatnya skor rerata $50 \%$ dalam mata kuliah kapita selekta matematika.

Sejumlah informasi permasalahan tersebut memunculkan pemikiran dari pengajar untuk mencari solusi yaitu diperlukannya suatu strategi dan pendekatan yang inovatif. Oleh karena itu agar terbentuk suatu pembelajaran yang dapat membentuk berpikir kritis maka diperlukan suatu pembelajaran yang mendukung tujuan tersebut. Inquiry Based Learning (pembelajaran berbasis inkuiri) adalah salah satu pendekatan yang dapat digunakan pengajar sebagai suatu strategi dan pendekatan yang inovatif. Pembelajaran berbasis inkuiri mencakup beberapa pendekatan yang berbeda yaitu meliputi: inkuiri terstruktur, inkuiri terbimbing, dan inkuiri terbuka (Colburn, 2000,hlm 42).

Latar belakang di atas mendorong penulis melakukan penelitian untuk melihat peningkatan kemampuan berpikir kritis mahasiswa PGSD melalui pembelajaran berbasis inkuiri yang mencakup: pendekatan inkuiri terstruktur, pendekatan inkuiri terbimbing dan pendekatan inkuiri terbuka. Oleh karena itu dalam penelitian ini penulis akan membandingkan peningkatan kemampuan berpikir kritis antara mahasiswa yang mendapatkan pembelajaran pendekatan inkuiri terstruktur, pendekatan inkuiri terbimbing, pendekatan inkuiri terbuka dengan mahasiswa yang mendapatkan pendekatan konvensional. Serta membandingkan peningkatan kemampuan berpikir kritis mahasiswa ditinjau latar belakang pendidikan mahasiswa (IPA, IPS, dan bahasa) dalam pembelajaran berbasis inkuiri. Selain itu penulis ingin mengetahui sikap mahasiswa dan tanggapan dosen terhadap pembelajaran matematika yang menggunakan pembelajaran berbasis inkuiri, serta faktor-faktor apa saja yang dapat mendukung atau menghambat pembelajaran matematika yang menggunakan pembelajaran berbasis inkuiri. Tujuan penelitian ini adalah untuk meningkatkan kualitas proses dan hasil pembelajaran matematika mahasiswa PGSD melalui pembelajaran matematika menggunakan pembelajaran berbasis inkuiri.

\section{B. TINJAUAN PUSTAKA}

\section{Pembelajaran Berbasis Inkuiri}

Salah satu metode pembelajaran yang tidak hanya menekankan produk matematika diantaranya ialah pembelajaran berbasis inkuiri. Sebelum membicarakan tentang pembelajaran berbasis inkuiri terlebih dahulu akan dijelaskan apa yang dimaksud dengan inkuiri. Metode inkuiri ialah metode mengajar yang serupa dengan metode penemuan. Bedanya ialah bahwa membawakan pengajaran penemuan pada umumnya dengan ekspositori dan kelompok kecil (laboratorium, diskusi), tetapi menyampaikan materi dengan inkuiri tidak perlu dengan cara demikian, menyampaikan materi inkuiri bisa dengan ekspositori, kelompok, dan sendiri-sendiri. Dalam metode penemuan sesuatu yang akan ditemukan mahasiswa sudah diketahui guru. Tetapi dalam inkuiri hal yang akan ditemukan oleh siswa belum dapat diketahui oleh guru. Dalam inkuiri guru adalah sebagai pengarah, pembimbing, dan sumber informasi. Pembelajaran inkuiri memiliki 4 tahap: 
1. Guru merangsang siswa dengan pertanyaan, masalah, permainan, dan teka-teki.

2. Sebagai jawaban atas rangsangan yang diterimanya, siswa menentukan prosedur mencari dan mengumpulkan informasi atau data yang diperlukan untuk memecahkan pertanyaan dan masalah.

3. Siswa menghayati pengetahuan yang diperolehnya dengan inkuiri yang baru dilaksanakan.

4. Siswa menganalisis metode inkuiri dan prosedur yang ditemukan untuk dijadikan metode umum yang dapat diterapkan ke situasi lain (tim MKPBM, 2001, hlm 180).

Menurut Colburn (2000, hlm 42), pembelajaran berbasis inkuiri ialah pembentukan kelas dimana siswa diikutsertakan secara essensial dalam aktivitas open ended, student centered dan hand-on. Selanjutnya menurut Colburn (2000, hlm 42), definisi pembelajaran berbasis inkuiri mencakup beberapa pendekatan yang berbeda yaitu meliputi: inkuiri terstruktur, inkuiri terpimpin, dan inkuiri terbuka.

Berdasarkan definisi pembelajaran berbasis inkuiri di atas dapat dirumuskan perbedaan ketiga pendekatan tersebut sebagai berikut:

\section{Tabel 1}

Perbedaan Pendekatan Inkuiri Terstruktur, Inkuiri Terbimbing dan Inkuiri Terbuka

\begin{tabular}{lccc}
\hline & $\begin{array}{c}\text { Inkuiri } \\
\text { Terstruktur }\end{array}$ & $\begin{array}{c}\text { Inkuiri } \\
\text { Terbimbing }\end{array}$ & $\begin{array}{c}\text { Inkuiri } \\
\text { Terbuka }\end{array}$ \\
\hline Pertanyaan & Guru & Guru & Siswa \\
Prosedur & Guru & Siswa & Siswa \\
Hasil & Siswa & Siswa & Siswa \\
\hline
\end{tabular}

Dalam pembelajaran inkuiri, para siswa mempelajari gejala ilmiah. Pendekatan inkuiri membawa siswa untuk bekerja seperti seorang peneliti. Para siswa mengalami proses mental tertentu diantaranya: (1) mengemukakan pertanyaan-pertanyaan tentang gejala alam, (2) merumuskan masalah, (3) merumuskan hipotesis, (4) merencanakan eksperimen, (5) melakukan eksperimen, (6) memadukan pengetahuan (sinthesizing problem), (7) mengembangkan sikap ilmiah, misalnya: objektif, ingin tahu, bersikap terbuka dan menaruh perhatian terhadap teoritis dan tanggung jawab (Sund \& Trowbridge, 1973,hlm 62-63). Guru harus mempunyai kepercayaan bahwa ia mempunyai kemampuan melebihi dari apa yang akan dikerjakan oleh siswa dan bagaimana akan dikerjakan oleh siswa (Colburn, 2000, hlm 43-44).

Berdasarkan riset, tingkah laku guru yang mengembangkan pembelajaran berbasis inkuiri yaitu mengidentifikasikan hal-hal sebagai berikut (Colburn, 2000, hlm 44).

1. Bertanya open ended, pertanyaan seperti:

Apa yang kamu kerjakan?

Jelaskan tentang apa yang kamu pikirkan?

Apa yang kamu pikirkan mengenai apa yang akan terjadi jika?

2. Menunggu beberapa detik setelah mengajukan pertanyaan, memberi waktu kepada siswa untuk berpikir.

3. Merespon siswa dengan mengulangi dan menguraikan apa yang telah mereka katakan tanpa memuji atau mengkritik.

4. Menghindari menyatakan apa yang siswa kerjakan, memuji, mengevaluasi, mencela atau melarang pendapat atau tingkah laku siswa.

5. Mempertahankan agar kelas tetap disiplin.

\section{Berpikir Kritis}

Berpikir kritis adalah suatu cara berpikir yang memeriksa hubunganhubungan serta mengevaluasi suatu situasi atau suatu masalah. Dalam hal 
seperti ini, termasuk didalamnya adalah kemampuan untuk mengumpulkan informasi, mengingat, serta menganalisis situasi. Termasuk pula dalam berpikir kritis ini adalah kemampuan untuk membaca serta memahami dan mengidentifikasi halhal diperlukan (Krulick dan Rudnick, 1999).

Penelitian pendidikan telah mengidentifikasi beberapa keterampilan yang berhubungan dengan kemampuan berpikir kritis yaitu menemukan analogi dan hubungan lainnya antar informasi, menentukan relevansi dan validitas informasi yang dapat digunakan untuk menyelesaikan masalah, dan menentukan dan mengevaluasi solusi atau cara-cara alternatif penyelesaian (Pott, 1994). Splitter (Mayadiana, 2005,hlm 9) bahwa orang yang berpikir kritis adalah individu yang berpikir, bertindak secara normatif, dan siap bernalar tentang kualitas dari apa yang mereka lihat, dengar, atau yang mereka pikirkan.

Dosen sebagai pendidik mahasiswa diharapkan dapat meningkatkan berpikir kritis mahasiswa agar dapat mencapai tujuan pembelajaran yang diharapkan. Cabrera (1992) mengungkapkan bahwa berpikir kritis merupakan proses dasar dinamis yang memungkinkan mahasiswa untuk menanggulangi dan mereduksi ketidaktentuan masa mendatang, sehingga sangatlah penting bagi para dosen untuk memperhatikan kemampuan mahasiswa dalam berpikir kritis.

Menurut Ennis (1996) berpikir kritis adalah suatu proses berpikir yang bertujuan untuk membuat keputusan yang rasional yang diarahkan untuk memutuskan apakah meyakini atau melakukan sesuatu. Dari definisi Ennis tersebut dapat diungkapkan beberapa hal penting. Berpikir kritis difokuskan kedalam pengertian sesuatu yang penuh kesadaran dan mengarah pada sebuah tujuan. Tujuan dari berpikir kritis adalah untuk mempertimbangkan dan mengevaluasi informasi yang pada akhirnya memungkinkan kita untuk membuat keputusan.

Berpikir kritis merupakan proses mental untuk menganalisis informasi yang diperoleh. Informasi tersebut didapatkan melalui pengamatan, pengalaman, komunikasi, atau membaca. Brookhart (2010). Selanjutnya Sukmadinata (2004) berpikir kritis adalah suatu kecakapan nalar secara teratur, kecakapan sistematis dalam menilai, memecahkan masalah, menarik keputusan, memberikan keyakinan, menganalisis asumsi, dan pencarian ilmiah. Berpikir kritis dari Chanche dan Sukmadinata mempunyai kesamaan yaitu proses mental untuk menganalisis, mengevaluasi, dan memecahan masalah. Melalui proses berpikir dengan kritis seseorang dapat memperoleh informasi dengan benar, mengevaluasinya dan memproses informasi tersebut sehingga diperoleh suatu kesimpulan yang terpercaya.

Swart dan Perkin (Hassoubah, 2004) menyatakan bahwa berpikir kritis berarti mencari dan menghimpun informasi yang dapat dipercaya untuk dipakai sebagai bukti yang dapat mendukung suatu penilaian. Dengan demikian berpikir kritis sebagian besar terdiri dari mengevaluasi argumen atau informasi dan membuat keputusan yang dapat membantu mengembangkan kepercayaan dan mengambil tindakan serta membuktikan.

Berpikir kritis yang akan diteliti penulis adalah berpikir kritis dalam matematika. Berpikir kritis di matematika tidak sama dengan non matematika. Ennis (Glazer, 2004) bahwa matematika merupakan domain yang memiliki kriteria berbeda untuk menyusun alasan yang tepat daripada kebanyakan bidang lainnya, karena matematika hanya menerima pembuktian deduktif, di mana kebanyakan bidang tidak memerlukannya untuk membangun kesimpulan akhir. 
Berpikir kritis matematis adalah berpikir kritis pada bidang ilmu matematika. Dengan demikian berpikir matematis adalah proses berpikir kritis yang melibatkan pengetahuan matematika, penalaran matematika dan pembuktian matematika. Berpikir kritis dalam matematika merupakan kemampuan berpikir kritis dalam menyelesaikan masalah matematika.

\section{METODE PENELITIAN}

Penelitian ini dilakukan untuk melihat hubungan sebab-akibat melalui pemanipulasian variabel bebas dan menguji perubahan yang diakibatkan oleh pemanipulasian tadi, sehingga penelitian ini digolongkan kepada penelitian eksperimen.

Perlakuan dalam penelitian ini adalah pembelajaran matematika dengan mengunakan pembelajaran berbasis inkuiri yang mencakup pendekatan inkuiri terstruktur, pendekatan terbimbing dan pendekatan inkuiri terbuka sebagai variabel bebas. Sementara kemampuan berpikir kritis matematik adalah sebagai variabel terikatnya (variabel yang diamati). Pengamatan dilakukan dua kali yaitu sebelum proses pembelajaran, yang disebut pretes dan sesudah pembelajaran yang disebut postes.

Pada penelitian ini, dipilih sampel penelitian secara acak, kemudian dibagi menjadi empat kelompok, yaitu tiga kelompok eksperimen dan satu kelompok kontrol. Pretes dan postes dilakukan pada empat kelompok tersebut. Pada kelompok eksperimen memperoleh perlakuan dengan pendekatan inkuiri terstruktur, pendekatan inkuiri terbimbing dan pendekatan inkuri terbuka sedangkan kelompok kontrol memperoleh perlakuan dengan pendekatan konvensional.

\section{HASIL DAN PEMBAHASAN}

Berdasarkan hasil data hasil penelitian, pembelajaran matematika dengan pendekatan inquiry based learning mempunyai potensi yang baik untuk dapat meningkatkan kemampuan berpikir kritis matematik mahasiswa. Hal ini dapat dilihat adanya perbedaan rerata peningkatan kemampuan berpikir kritis matematik untuk kelas eksperimen yang terdiri dari kelas inkuiri terstruktur, kelas inkuiri terbimbing dan kelas inkuiri terbuka dan kelas kontrol pada skor pretes-postes yang mencolok.

Dengan skor ideal 50 diperoleh data pada kelas inkuiri terstruktur yaitu skor rerata pretes $\bar{x}_{\text {pretes-eksperimen }}=5,28$, meningkat menjadi $\bar{x}_{\text {postes-eksperimen }}=18,62$ pada skor postes, dengan rerata peningkatan $\bar{x}_{\mathrm{g}}=0,3002$, tergolong dalam katagori sedang. Pada kelas inkuiri terbimbing skor rerata pretes $\bar{x}_{\text {pretes-eksperimen }}$ $=5,46$, meningkat menjadi $\bar{x}_{\text {postes-eksperimen }}=$ 18,65 pada skor postes, dengan rerata peningkatan $\bar{x}_{g}=0,302$, tergolong dalam katagori sedang. Pada kelas inkuiri terbuka skor rerata pretes $\bar{x}_{\text {pretes-eksperimen }}=5,84$, meningkat menjadi $\bar{x}_{\text {postes-eksperimen }}=21$ pada skor postes, dengan rerata peningkatan $\bar{x}_{\mathrm{g}}=0,35$, tergolong dalam katagori sedang. Pada kelas kontrol skor rerata pretes $\bar{x}_{\text {pretes-eksperimen }}=5,43$, meningkat menjadi $\bar{x}_{\text {postes-eksperimen }}=10,15$ pada skor postes, dengan rerata peningkatan $\bar{x}_{\mathrm{g}}=0,1$ tergolong dalam katagori rendah.

Berdasarkan hasil penelitian terlihat bahwa pembelajaran berbasisis inkuiri lebih baik daripada pembelajaran konvensional. Hal ini disebabkan karena pada kelas berbasis inkuiri setiap pembelajarannya selalu diawali oleh masalah, konsep ditemukan sendiri oleh mahasiswa dan proses pembelajaran berpusat pada mahasiswa.

Berdasarkan hasil penelitian terlihat bahwa pembelajaran matematika berbasis 
inkuiri memberi kesempatan pada mahasiswa untuk : (1) mengembangkan keinginan dan motivasi mahasiswa untuk mempelajari prinsip dan konsep matematika; (2) mengembangkan keterampilan ilmiah mahasiswa sehingga mampu bekerja seperti layaknya seorang ilmuwan; (3) membiasakan mahasiswa bekerja keras untuk memperoleh pengetahuan.

Proses inkuiri memberi kesempatan kepada mahasiswa untuk memiliki pengalaman belajar yang nyata dan aktif, siswa dilatih bagaimana memecahkan masalah sekaligus membuat keputusan. Pembelajaran berbasis inkuri memungkinkan siswa belajar sistem, karena pembelajaran inkuiri memungkinkan terjadi integrasi berbagai disiplin ilmu. Ketika siswa melakukan eksplorasi, akan muncul pertanyaanpertanyaan yang melibat matematika, bahasa, ilmu sosial, seni, dan juga teknik. Peran guru di dalam pembelajaran inkuiri lebih sebagai pemberi bimbingan, arahan jika diperlukan oleh mahasiswa. Dalam proses inkuiri mahasiswa dituntut bertanggungjawab penuh terhadap proses belajarnya, sehingga guru harus menyesuaikan diri dengan kegiatan yang dilakukan oleh siswa, sehingga tidak menganggu proses belajar mahasiswa.

Pembelajaran dengan berbasis inkuiri pada intinya adalah semua kegiatan pembelajaran di kelas adalah berpusat pada mahasiswa, sehingga terkadang mahasiswa berhasil menemukan sesuatu yang tidak diperkirakan oleh dosen sebelumnya. Manfaat paling berharga dalam pembelajaran inkuiri adalah para mahasiswa menjadi aktif, memandang matematika menjadi menyenangkan dan pemahaman konsep matematika yang mereka temukan lama untuk diingat. Hal ini sejalan dengan pendapat John Dewey (Ibrahim, 2007) bahwa inti dari inkuiri adalah proses yang berpusat pada siswa.
Semua pembelajaran dimulai dengan pebelajar. Apa yang diketahui siswa dan apa yang ingin mereka lakukan dan pelajari merupakan dasar utama pembelajaran.

Dalam data hasil penelitian nampak ada perbedaan rerata antara ketiga kelas inkuiri. Rerata kemampuan berpikir kritis matematika pada kelas inkuiri terstruktur dan kelas inkuiri terbimbing perbedaan tidak terlalu mencolok. Hal ini disebabkan karena masalah dari kedua kelas sama, prosedur penyelesaiannya dari kedua kelas tersebut masih bersumber pada dosen, yang membedakan antara keduanya adalah kelas inkuiri terstruktur prosedur penyelesaiannya dibuat secara tertulis sedangkan pada kelas inkuiri terbimbing walaupun dibuat oleh mahasiswa namun kontribusi dosen masih ada melalui bimbingan secara lisan.

Rerata kemampuan berpikir kritis matematik pada kelas inkuiri terbuka lebih tinggi dari kedua kelas inkuiri lainnya. Hal ini disebabkan karena permasalahan dan prosedur penyelesaian berasal dari mahasiswa, kontribusi dosen hanya memberikan arahan saja. Mahasiswa yang kesulitan akan dibantu oleh mahasiswa dan semua proses pembelajaran terpusat pada mahasiswa. Berdasarkan penelitian yantg diperoleh, pembelajaran inkuiri akan efektif jika diberikan pada mahasiswa dari yang sederhana kepada pembelajaran inkuiri yang lebih komplek. Kemudian pembelajaran berbasis inkuiri akan berjalan baik jika setiap mahasiswa mempunyai dasar-dasar inkuiri sebelumnya. Hal ini sejalan dengan pendapat Bonnstetter (Ibrahim, 2007) membedakan inkuiri menjadi lima tingkat dari yang sederhana pada yang lebih komplek, yaitu praktikum (tradisional hands-on), inkuiri terstruktur (structured inquiry), inkuiri terbimbing (guided inquiry), inkuiri terbuka (open inquiry) dan penelitian mahasiswa (student research). 
Selain melihat perbedaan rerata antara kelas yang belajar dengan pendekatan berbasis inkuiri dan yang belajar dengan konvensional. Peneliti tertarik untuk melihat pengaruh pembelajaran berbasis inkuri terhadap kelompok IPA, kelompok IPS dan kelompok bahasa. Berdasarkan data postes yang diperoleh, kelompok IPA lebih dominan dari kelompok IPS dan kelompok bahasa. Dengan skor ideal 50 diperoleh data yaitu, kelompok IPA skor rerata pretes $\bar{x}_{\text {pretes-eksperimen }}=15,9$ meningkat menjadi $\bar{x}_{\text {postes-eksperimen }}=22,68$ pada skor postes, dengan rerata peningkatan $\bar{x}_{g}=$ 0,5 , tergolong dalam katagori sedang. Kelompok IPS skor rerata pretes $\bar{x}_{\text {pretes- }}$ eksperimen $=11,3$ meningkat menjadi $\bar{x}_{\text {postes- }}$ eksperimen $=15,39$ pada skor postes, dengan rerata peningkatan $\bar{x}_{g}=0,3$, tergolong dalam katagori sedang. Kelompok bahasa skor rerata pretes $\bar{x}_{\text {pretes-eksperimen }}=8,3$ meningkat menjadi $\bar{x}_{\text {postes-eksperimen }}=10,33$ pada skor postes, dengan rerata peningkatan $\bar{x}_{\mathrm{g}}=0,2$ tergolong dalam katagori rendah.

Jika kita lihat pada rerata tiap kelompok pada tiap kelas inkuiri, ditemukan bahwa kelompok IPA memiliki kesesuaian dengan kegiatan inkuiri, semakin banyak masalah yang dirumuskan memberikan dampak yang signifikan terhadap kemampuan berpikir kritis mahasiswa. Hal ini didukung oleh konsep awal dari kelompok IPA yang mereka diperoleh saat di SMA. Sedangkan untuk kelompok IPS dan kelompok bahasa yang memiliki konsep awal yang kurang terhadap matematika, berdasarkan hasil penelitian yang diperoleh. Kelompok IPS dan kelompok bahasa dapat menyesuaikan dengan kegiatan inkuiri jika mendapatkan bimbingan dari dosen.

Berdasarkan pengamatan peneliti bahwa: a) kelompok IPA lebih cocok dengan pendekatan inkuiri terbuka dikarenakan pembelajaran terpusat pada mahasiswa baik dalam penyusunan masalah dan pemilihan prosedur penyelesainnya, b) kelompok IPS dan Bahasa tidak cocok dengan pendekatan inkuri terbuka dikarenakan hampir seluruh mahasiswa belum mempunyai dasar-dasar inkuiri sebelumnya sehingga dalam proses pembelajaran memerlukan bimbingan dari dosen, dan c) pendekatan inkuiri terstruktur dan inkuiri terbimbing lebih tepat untuk kelompok IPS dan Bahasa dikarenakan prosedur penyelesaian masalah yang mereka miliki dapat langsung diterapkan dalam menyelesaikan masalah tanpa harus mencari terlebih dahulu. Selain itu, prosedur penyelesain masalahan pada kelompok IPS dan Bahasa mendapat bimbingan dosen.

Keberhasilan pembelajaran matematika dengan pendekatan berbasis inkuiri dalam meningkatkan kemampuan berpikir kritis matematik tidak lain adalah karena adanya peran aktif mahasiswa. Aktivitas mahasiswa lebih dominan dibandingkan dengan aktivitas dosen (menyampaikan informasi dengan menulis/ceramah). Dosen di sini lebih berperan sebagai fasilitator dan mediator pembelajaran. Kegiatan belajar melalui inkuiri menghadapkan mahasiswa pada pengalaman kongkrit sehingga siswa belajar secara aktif, di mana mereka didorong untuk mengambil inisiatif dalam usaha memecahkan masalah, mengambil keputusan, dan mengembangkan keterampilan meneliti serta melatih siswa menjadi pebelajar sepanjang hayat.

Melalui kegiatan inkuiri, siswa dengan tingkat perkembangan atau kemampuan yang berbeda dapat bekerja pada masalah-masalah sejenis dan berkolaborasi untuk menemukan pemecahannya. Dalam proses inkuiri, pebelajar termotivasi untuk terlibat langsung atau berperan aktif secara fisik dan mental dalam kegiatan belajar. Lingkungan kelas di mana pebelajar aktif 
terlibat dan guru berperan sebagai fasilitator pembelajaran sangat membantu tercapainya kompetensi atau tujuan pembelajaran. Implementasi inkuiri sangat didukung oleh prinsip-prinsip pembelajaran yang bersandar pada teori konstruktivisme yaitu: 1) belajar dengan melakukan, 2) belajar untuk mengembangkan kemampuan sosial atau kerjasama, dan 3) belajar untuk mengembangkan keterampilan memecahkan masalah. inkuiri diharapkan dapat memberikan kesempatan dengan lebih leluasa kepada siswa untuk belajar dan bekerja melalui proses inkuiri sebagaimana seorang ilmuwan atau peneliti bekerja.

Mahasiswa memiliki kesempatan untuk bekerjasama dalam membangun pemahaman dan keterampilannya melalui interaksi dengan lingkungan sosial seperti teman sejawat, guru dan sumber-sumber belajar lain. Interaksi dengan lingkungan memungkin-kan seorang mahasiswa memperbaiki pemahaman dan memperkaya pengetahuannya melalui kegiatan bertanya jawab atau berdiskusi dalam kelompok belajarnya. Inkuiri mendukung prinsip ini karena pada dasarnya kegiatan inkuiri dirancang agar siswa belajar dalam kelompok dan guru berperan sebagai pembimbing dan fasilitator. Sebagaimana pendapat Ruseffendi (2006), bahwa keberhasilan siswa belajar tidak hanya sekedar berhasil belajar, tetapi keberhasilan belajar yang ditempuhnya dengan belajar aktif.

Peningkatan kemampuan berpikir kritis matematik mahasiswa ini juga didukung oleh adanya tanggapan positif dari dosen dan mahasiswa terhadap proses pembelajaran. Dosen (observer) berpendapat bahwa, pembelajaran berbasis inkuiri baik untuk diterapkan dalam proses pembelajaran matematika di PGSD karena membiasakan mahasiswa melakukan kegiatan pemecahan masalah. Adanya pembelajaran dengan inkuiri dapat membantu mahasiswa bekerja sama dengan temannya untuk menemukan konsep-konsep yang ada dalam matematika.

Pembelajaran berbasis inkuiri juga dapat merangsang mahasiswa rajin membaca buku-buku matematika, sebagai bekal dalam memahami konsep. Pemahaman materi lebih mendalam sebab mahasiswa menemukan sendiri konsepkonsep matematika sendiri baik dengan sendiri dan diskusi kelompok.

Secara umum respon mahasiswa terhadap pembelajaran berbasis inkuiri adalah positif. Hal ini didukung oleh tingginya persentase sikap positif mahasiswa dari 20 pertanyaan skala sikap. Dapat dilihat juga dari perhitungan rerata skor sikap mahasiswa yang menunjukkan bahwa rerata skor sikap mahasiswa lebih besar dibandingkan dengan rerata skor netralnya. Selain itu, rangkuman jurnal harian pada tiap pertemuan dan wawancara mahasiswa memberikan kesan positif pada pembelajaran berbasis inkuiri.

Meskipun hanya 74,5 \% mahasiswa menyetujui pembelajaran berbasis inkuiri dan sisanya $25,5 \%$ atau kurang lebih 24 orang tidak setuju terhadap pembelajaran berbasis inkuiri. Hal ini dikarenakan mahasiswa mengeluhkan waktu yang relatif lama, belum terbiasa dengan pembelajaran inkuiri, konsep awal yang dimiliki relatif kurang dan kesan negatif saat di SMA terhadap matematika yang masih melekat sampai PGSD.

Hambatan dalam pembelajaran dengan pendekatan berbasis inkuiri adalah: (1) Mahasiswa belum terbiasa dengan pembelajaran berbasis inkuiri. Hal ini mengakibatkan kurang tangung jawab dan kesadaran tiap mahasiswa dalam kelompoknya, yaitu mengemukakan ide, mengajukan masalah, bagaimana ia harus bekerjasama dalam kelompok, mereka masih senang belajar sendiri-sendiri dalam 
menemukan konsep-konsep matematika, frekuensi bertanya lebih sering ditujukan kepada dosen sebelum bertanya kepada teman lain dalam kelompoknya.mereka belum punya kepercayaan diri ketika harus menjadi tutor teman sebaya dalam kelompoknya dan menyampaikan hasil penemuan di depan kelas; (2) Proses pembelajaran berbasis inkuiri membutuhkan waktu yang lama dibandingkan dengan proses pembelajaran konvensional; (3) Jika jumlah masalah terlalu banyak, maka sebagain mahasiswa merasa keberatan karena otomatis proses berpikir pun akan relatif tinggi.

Pendukung pembelajaran berbasis inkuiri pada pembelajaran matematika, diantaranya adalah: (1) Adanya antusias dan motivasi yang tinggi pada mahasiswa dalam setiap proses pembelajaran; (2) Mahasiswa mempunya kebanggaan saat berhasil berhasil menemukan konsep matematika; (3) Lembar Kerja Mahasiswa yang menyajikan proses inkuiri yang baik; (4) bimbingan dosen yang maksimal dalam memberikan arahan bagi mahasiswa dalam proses menemukan konsep mahasiswa; (5) Suasana kelas yang tenang, karena jika gaduh, pada umumnya mahasiswa tidak bisa konsentrasi menemukan konsep jika suasana di luarnya kelas tidak mendukung.

\section{E. KESIMPULAN}

Berdasarkan hasil analisis dan pembahasan dari bab sebelumnya, maka dapat disimpulkan bahwa tanggapan mahasiswa terhadap pembelajaran berbasis inkuiri adalah positif. Hal ini didukung oleh tingginya persentase sikap positif dari 20 butir pertanyan skala sikap. Dapat dilihat juga dari perhitungan rerata skor sikap mahasiswa yang menunjukan bahwa rerata skor sikap mahasiswa lebih besar dibandingkan dengan rerata skor netralnya.

Tanggapan dosen terhadap pembelajaran berbasis inkuiri adalah positif. Dosen (observer) berpendapat bahwa, pembelajaran berbasis inkuiri baik untuk diterapkan dalam proses pembelajaran matematika di PGSD karena membiasakan mahasiswa melakukan kegiatan pemecahan masalah. Adanya pembelajaran dengan inkuiri dapat membantu mahasiswa bekerja sama dengan temannya untuk menemukan konsep-konsep yang ada dalam matematika. Selain itu pembelajaran berbasis inkuiri juga dapat merangsang mahasiswa rajin membaca buku-buku matematika, sebagai bekal dalam memahami konsep. Pemahaman materi lebih mendalam sebab mahasiswa menemukan sendiri konsep-konsep matematika sendiri baik dengan sendiri dan diskusi kelompok.

Hambatan dalam pembelajaran dengan pendekatan berbasis inkuiri adalah: (1) Mahasiswa belum terbiasa dengan pembelajaran berbasis inkuiri dalam mengatasinya setiap pertemuan mahasiswa diberikan informasi mengenai pembelajaran inkuiri yang diterapkan. Akibat belum terbiasa mengikuti pembelajaran inkuiri mengakibatkan kurang tangung jawab dan kesadaran tiap mahasiswa dalam kelompoknya, yaitu mengemukakan ide, mengajukan masalah, bagaimana ia harus bekerjasama dalam kelompok, mereka masih senang belajar sendiri-sendiri dalam menemukan konsepkonsep matematika, frekuensi bertanya lebih sering ditujukan kepada dosen sebelum bertanya kepada teman lain dalam kelompoknya, mereka belum punya kepercayaan diri ketika harus menjadi tutor teman sebaya dalam kelompoknya dan menyampaikan hasil penemuan di depan kelas; (2) Proses pembelajaran berbasis inkuiri membutuhkan waktu yang lama 
dibandingkan dengan proses menemukan konsep matematika; pembelajaran konvensional; (3) Jika (3) Lembar Kerja Mahasiswa yang jumlah masalah terlalu banyak, maka menyajikan proses inkuiri yang baik; (4) sebagian mahasiswa merasa keberatan Bimbingan dosen yang maksimal dalam karena otomatis proses berpikir pun akan memberikan arahan bagi mahasiswa relatif tinggi. Pendukung pembelajaran dalam proses menemukan konsep berbasis inkuiri pada pembelajaran mahasiswa; (5) Suasana kelas yang matematika, diantaranya adalah: (1) tenang, karena jika gaduh, pada umumnya Adanya motivasi yang tinggi pada mahasiswa tidak bisa konsentrasi mahasiswa dalam setiap proses menemukan konsep jika suasana di pembelajaran; (2) Mahasiswa mempunya kebanggaan saat berhasil berhasil luarnya kelas tidak mendukung.

\section{DAFTAR PUSTAKA}

Brookhart, S. M. (2010). How to assess higher-order thinking skills in your classroom. ASCD. Cabrera, G. A. (1992). A framework for evaluating the teaching of critical thinking. Education, 113(1), 59-63.

Colburn, A. (2000). An inquiry primer. Science scope, 23(6), 42-44.

Ennis, R. H. (1996). Critical thinking dispositions: Their nature and assessability. Informal logic, 18(2).

Glazer, E. (2004). Technology Enhanced Learning Environtments that are Conductive to Critical Thinking in Mathematics: Implication for Research about Critical Thinking on the World Wide Web [Online]. Tersedia: http://www.lonestar.texas.net mseifert/crit2.html

Hassoubah, Z.I. (2004). Developing Creative \& Critical Thinking Skills. Bandung: Nuansa.

Hendriana, H. (2012). Pembelajaran matematika humanis dengan metaphorical thinking untuk meningkatkan kepercayaan diri siswa. Infinity Journal, 1(1), 90-103.

Ibrahim, M. (2007). Pembelajaran Inkuiri [Online].Tersedia: http://agungprudent.wordpress.com/2009/05/27/model-pembelajaran-inkuiri-2

Krulik, S., \& Rudnick, J. A. (1999). Innovative tasks to improve critical and creative thinking skills. from Developing Mathematical reasoning in Grades K-12, 138-145.

Maulana. (2007). Pendekatan Metakognitif sebagai Alternatif Pembelajaran Matematika untuk Meningkatkan Kemampuan Berpikir Kritis Mahasiswa PGSD. Tesis SPs UPI. Bandung

Mayadiana, D. (2005). Pembelajaran dengan Pendekatan Diskursif untuk Mengembangkan Kemampuan Berpikir Kritis Mahasiswa Calon Guru SD (Doctoral dissertation, Tesis pada PPs Universitas Pendidikan Indonesia.

Pott, B. (1994). Strategies for Teaching Critical Thinking. Practical Asessment, Research and Evaluation. 
Ruseffendi, E. T. (2006). Pengantar kepada membantu guru mengembangkan kompetensinya dalam pengajaran matematika untuk meningkatkan CBSA. Bandung: Tarsito

Siagian, R. E. F. (2015). Pengaruh minat dan kebiasaan belajar siswa terrhadap prestasi belajar matematika. Formatif: Jurnal IImiah Pendidikan MIPA, 2(2).

Sukmadinata, N. S., \& Syaodih, E. (2004). Kurikulum dan pembelajaran kompetensi. Bandung: Yayasan Kesuma Karya.

Sund, R. B., \& Trowbridge, L. W. (1973). Teaching science by inquiry in the secondary school. Merrill Publishing Company.

Supriadi. (2005). Pengamatan Kemajuan Pembelajaran Matematika PGSD UPI Serang. Makalah.

Tim MKPBM (2001). Strategi Pembelajaran Matematika Kontemporer. Bandung: JICA-UPI.

Tiurlina. (2005). Pemahaman Matematika Mahasiswa PGSD. Jurnal UPI PGSD 